\title{
Antinociceptive Effect of the Essential Oil Obtained from the Leaves of Croton cordiifolius Baill. (Euphorbiaceae) in Mice
}

\author{
Lenise de Morais Nogueira, ${ }^{1}$ Monalisa Ribeiro da Silva, ${ }^{1}$ Simone Maria dos Santos, ${ }^{2}$ \\ Julianna Ferreira Cavalcanti de Albuquerque, ${ }^{2}$ Igor Cavalcanti Ferraz, ${ }^{3}$ \\ Thaíse Torres de Albuquerque, ${ }^{3}$ Carlos Renato França de Carvalho Mota, ${ }^{3}$ \\ Renata Mendonça Araújo, ${ }^{4}$ Glauce Socorro de Barros Viana, ${ }^{1}$ René Duarte Martins, ${ }^{3}$ \\ Alexandre Havt, ${ }^{1}$ and Rafael Matos Ximenes ${ }^{2}$ \\ ${ }^{1}$ Departamento de Fisiologia e Farmacologia, Universidade Federal do Ceará, Rua Coronel Nunes de Melo 1127, \\ 60430-270 Fortaleza, CE, Brazil \\ ${ }^{2}$ Departamento de Antibióticos, Universidade Federal de Pernambuco, Rua Professor Artur de Sá, s/n, 50740-520 Recife, PE, Brazil \\ ${ }^{3}$ Centro Acadêmico de Vitória, Universidade Federal de Pernambuco, Rua Alto do Reservatório, $s / n$, \\ 55608-680 Vitória de Santo Antão, PE, Brazil \\ ${ }^{4}$ Instituto de Química, Universidade Federal do Rio Grande do Norte, Avenida Senador Salgado Filho 3000, \\ 50078-970 Natal, RN, Brazil
}

Correspondence should be addressed to Rafael Matos Ximenes; ximenesrm@gmail.com

Received 25 November 2014; Revised 28 January 2015; Accepted 29 January 2015

Academic Editor: Olumayokun A. Olajide

Copyright (C) 2015 Lenise de Morais Nogueira et al. This is an open access article distributed under the Creative Commons Attribution License, which permits unrestricted use, distribution, and reproduction in any medium, provided the original work is properly cited.

\begin{abstract}
Croton cordiifolius Baill. is a shrub known as "quebra-faca" and is used to treat inflammation, pain, wounds, and gastrointestinal disturbances in the semiarid region in the northeast of Brazil. In an ethnobotanical survey in the state of Pernambuco, "quebra-faca" use was cited in $33 \%$ of the interviews. Thus, we decided to evaluate the antinociceptive effects of the essential oil from C. cordiifolius (CcEO). Chemical analysis by gas chromatography-mass spectrometry revealed 1,8-cineole (25.09\%) and $\alpha$-phellandrene (15.43\%) as major constituents. Antinociceptive activity was evaluated using murine models of chemically induced pain (writhing induced by acetic acid, formalin, capsaicin, and glutamate tests). Opioid and central nervous systems (CNS) involvement were also investigated. Regarding antinociceptive activity, CcEO (50 and $100 \mathrm{mg} / \mathrm{kg}$ ) reduced the number of writhing responses induced by acetic acid and decreased the licking times in both phases of the formalin test. CcEO also was evaluated in capsaicin- and glutamate-induced nociception. While no effect was observed in the capsaicin test, $\mathrm{CcEO}(100 \mathrm{mg} / \mathrm{kg})$ was effective in the glutamate test. Naloxone, an opioid antagonist, did not affect the antinociceptive activity of CcEO in writhing test. In conclusion, the antinociceptive effect of CcEO could be explained, at least in part, by inhibition of the glutamatergic system.
\end{abstract}

\section{Introduction}

Croton is the second largest genus of the Euphorbiaceae family with approximately 1,200 species. Croton has a pantropical distribution, mainly in the Americas, and about 350 species are found in Brazil [1]. Croton spp. are rich sources of secondary metabolites including alkaloids, flavonoids, and terpenoids, which are responsible for the therapeutic properties of many Croton species [2].
Many pharmacological activities are related to Croton spp., such as antinociceptive, anti-inflammatory, wound healing, anticancer, and antimicrobial activities [3-8]. However, the pharmacological potential of many species remains completely unexplored.

Three Croton species are known as "quebra-faca" in the semiarid region of the northeast of Brazil: Croton cordiifolius Baill., Croton conduplicatus Kunth., and Croton heliotropiifolius Kunth. [9]. Beside sharing the same popular name, 
these species are used to treat the same medical conditions, such as general inflammation, pain, and gastrointestinal disturbances $[10,11]$.

To date, no data about the chemistry and pharmacological properties of Croton cordiifolius Baill. could be found in literature. Thus, we performed an ethnobotanical survey, and after analyzing the data, we decided to investigate the role of the essential oil obtained from the leaves of $C$. cordiifolius $(\mathrm{CcEO})$ in its claimed antinociceptive activity, since essential oils, in general, exhibit antimicrobial, anti-inflammatory, and antinociceptive properties [7].

\section{Material and Methods}

2.1. Ethnobotanical Survey. Ethnobotanical data were collected through semistructured interviews in two phases [12]. Informed free consent terms were obtained from those who offered to participate in the study, following the legal and ethical regulations set out in the 196/96 resolution from the Ethics Committee on Research of the Ministry of Health, Brazil. In the first phase, the following guiding question was used: what medicinal plants to treat inflammation and pain do you know about? Subsequently, details concerning the part of the plant used, preparation method, indications, and contraindications of each species mentioned were recorded. In the second phase, after analysis of data from the first phase, one specimen of C. cordiifolius was shown to the interviewees for recognition. Data were collected between January and March of 2011 in the urban and rural areas of the cities of Salgueiro, TerraNova, Parnamirim, and Serrita, which are all located in the state of Pernambuco, in the central region of the northeast of Brazil. One hundred people of both sexes were interviewed.

The use value (UV) of C. cordiffolius was calculated according to the formula described by Rossato et al. [13]:

$$
\mathrm{UV}=\frac{\Sigma U i}{n}
$$

where $U i=$ the number of uses cited by each informant and $n=$ the total number of informants.

2.2. Plant Material. Leaves of Croton cordiifolius Baill. were collected in the morning during the flowering period (April $2011)$ in the rural area of Salgueiro, Pernambuco, Brazil $\left(-8^{\circ}\right.$ $\left.04^{\prime} 27^{\prime \prime} \mathrm{S},-39^{\circ} 07^{\prime} 09^{\prime \prime} \mathrm{W}, 420 \mathrm{~m}\right)$. The botanical material was authenticated by botanist Maria Olívia de Oliveira Cano of the Herbarium of the Agronomic Institute of Pernambuco (IPA). A voucher specimen was deposited under the number 85,609 .

2.3. Essential Oil Extraction. Fresh leaves were submitted immediately for hydrodistillation at $96^{\circ} \mathrm{C}$ for $2 \mathrm{~h}$ in a Clevenger-type apparatus. The essential oil subsequently was dried over anhydrous sodium sulfate while protected from light and frozen at $-20^{\circ} \mathrm{C}$ until use.

For the pharmacological assays, the density of the essential oil was determined using a $1 \mathrm{~mL}$ pycnometer, and then the doses were calculated. CcEO was suspended in $0.5 \%$ Cremophor (Sigma-Aldrich, St. Loius, MO, USA) and sonicated before use.
2.4. Chemical Analysis. Gas chromatography and mass spectrometry (GC/MS) were conducted at the Technological Development Park of the Federal University using a GC/MS QP 5050A (Shimadzu, Kyoto, Japan) and an Agilent DB-5ms nonpolar capillary column $(50 \mathrm{~m} \times 0.25 \mathrm{~mm} \times 0.25 \mu \mathrm{m})$. The oven temperature was programmed at $70^{\circ} \mathrm{C}$ with an increase of $4^{\circ} \mathrm{C} / \mathrm{min}$ until $280^{\circ} \mathrm{C}$ was reached and then maintained for $15 \mathrm{~min}$. The carrier gas was helium, with a constant flow rate of $1.4 \mathrm{~mL} / \mathrm{min}$. The temperature of the ionization source was maintained at $280^{\circ} \mathrm{C}$, ionization energy at $70 \mathrm{eV}$, and ionization current at $0.7 \mathrm{kV}$. Mass spectra were recorded from 30 to $450 \mathrm{~m} / \mathrm{z}$. Individual components were identified by matching their $70 \mathrm{eV}$ mass spectra with those of the spectrometer database by using the Wiley L-Built library and by comparing their retention indices and fragmentation patterns with those of the NIST [14] MS library and those reported in the literature [15], respectively. The retention indices were compared with those obtained by Craveiro et al. [16] for other Euphorbiaceae species and simulated using the method described by Alencar et al. [17]. ${ }^{1} \mathrm{H}$ and ${ }^{13} \mathrm{C}$ NMR were recorded on a Bruker Avance DRX-300 (300 MHz for ${ }^{1} \mathrm{H}$ and $75 \mathrm{MHz}$ for ${ }^{13} \mathrm{C}$ ); chemical shifts are given in $\mathrm{ppm}$ relative to residual $\mathrm{CHCl}_{3}$ (7.27) and to the central peak of the triplet related to $\mathrm{CDCl}_{3}$ carbon $(77.2 \mathrm{ppm})$.

2.5. Chemicals and Drugs. Acetic acid and $37 \%$ formaldehyde were from Merck (Brazil, São Paulo). Capsaicin, glutamate, indomethacin, and polyethoxylated castor oil (Cremophor) were from Sigma (USA, St. Louis). Morphine and naloxone were purchased from Cristália (Brazil, São Paulo), while diazepam was from União Química (Brazil, São Paulo). All other reagents and substances were of analytical grade.

2.6. Animals. Male Swiss mice (25-30g, $n=8$ ) were provided by the Animal Facility of the Federal University of Pernambuco. The animals were housed and kept in a room with controlled temperature $\left(23 \pm 2^{\circ} \mathrm{C}\right)$ under a $12 / 12 \mathrm{~h}$ light/dark cycle with food and water ad libitum. Experiments were carried out according to the Guide for the Care and Use of Laboratory Animals of the US Department of Health and Human Services (NIH publication number 85-23, revised in 1985). The project had been previously approved by the Animal's Ethics Committee of Federal University of Pernambuco (number 23076.020508/2010-26).

2.7. Acute Toxicity. A limit test of $1,000 \mathrm{mg} / \mathrm{kg}$ was performed according to OECD 425 guideline [18] to determine the acute toxicity of the essential oil using few animals. The CcEO $(1,000 \mathrm{mg} / \mathrm{kg}$, i.p. $)$ was administered to one animal followed by $24 \mathrm{~h}$ of observation. As this animal did not die, two more animals were administered with $\mathrm{CcEO}(1,000 \mathrm{mg} / \mathrm{kg}$, i.p.) under the same conditions. A total of five animals were used. After the long-term observation of 14 days, the animals were killed and gross necropsy carried out.

2.8. Acetic Acid Induced Writhing. The acetic acid induced writhing was performed according to the protocol described by Koster et al. [19] with some modifications [8]. C. cordiifolius essential oil (50 and $100 \mathrm{mg} / \mathrm{kg}$, i.p.) or indomethacin 
(10 mg/kg, i.p.) was given $30 \mathrm{~min}$ before the administration of a $0.6 \%$ acetic acid solution $(10 \mathrm{~mL} / \mathrm{kg}$, i.p.). After $10 \mathrm{~min}$, the number of writhing was counted for $20 \mathrm{~min}$ by a blind observer.

2.9. Formalin Induced Nociception. Twenty microliters of $1 \%$ formalin solution were administered (s.c.) to each mouse's right hind paw. Licking time was recorded from 0 to $5 \mathrm{~min}$ (phase 1, neurogenic) and from 20 to $25 \mathrm{~min}$ (phase 2, inflammatory) after formalin injection [20]. The animals were treated with vehicle $(10 \mathrm{~mL} / \mathrm{kg}$, i.p. $)$, morphine $(7.5 \mathrm{mg} / \mathrm{kg}$, i.p.), or $\mathrm{CcEO}$ (50 and $100 \mathrm{mg} / \mathrm{kg}$, i.p.) $30 \mathrm{~min}$ before the formalin administration.

2.10. Capsaicin Induced Nociception. After an acclimatization period of $20 \mathrm{~min}$, the animals received $20 \mu \mathrm{L}$ of capsaicin $(1.6 \mu \mathrm{g} /$ paw freshly prepared in PBS) by intraplantar injection in the right hindpaw. Animals were observed individually for 5 min following capsaicin injection. The amount of time spent licking the injected paw was timed and considered as indicative of nociception [21]. The animals were treated with vehicle (10 mL/kg, i.p.) or CcEO (50 and $100 \mathrm{mg} / \mathrm{kg}$, i.p.) $30 \mathrm{~min}$ before the capsaicin administration.

2.11. Glutamate Induced Nociception. Animals received an intraplantar injection of $20 \mu \mathrm{L}$ of glutamate $(20 \mu \mathrm{mol} / \mathrm{paw}$ prepared in PBS) in the right hindpaw. The amount of time they spent licking the injected paw during the observation period of $15 \mathrm{~min}$ following glutamate injection was recorded with a chronometer and considered indicative of nociception [22]. Animals were treated with vehicle $(10 \mathrm{~mL} / \mathrm{kg}$, i.p. $)$ or $\mathrm{CcEO}(50$ and $100 \mathrm{mg} / \mathrm{kg}$, i.p.) $30 \mathrm{~min}$ before the glutamate injection.

2.12. Evaluation of Opioid Involvement. To assess the possible involvement of the opioid system in the antinociceptive effect of the essential oil, mice were treated with naloxone $(1 \mathrm{mg} / \mathrm{kg}$, i.p.) 15 minutes prior the administration of the CcEO (100 mg/kg, i.p.), morphine (7.5 mg/kg, i.p.), or vehicle $(10 \mathrm{~mL} / \mathrm{kg}$, i.p.). Thirty minutes later, the animals received $0.6 \%$ acetic acid solution $(10 \mathrm{~mL} / \mathrm{kg}$, i.p.). After $10 \mathrm{~min}$, the number of writhing was counted during $20 \mathrm{~min}$ [23].

2.13. Evaluation of the Locomotor Activity. The open-field test was used to evaluate the effect of $C$. cordiifolius essential oil on locomotor activity of mice. An acrylic box (transparent walls and black floor) measuring $30 \times 30 \times 15 \mathrm{~cm}$ and divided in nine squares of equal area was used. Mice were placed inside the box during 5 minutes. During the analysis, the number of squares crossed with all paws, rearing and grooming were counted and used as an indication of locomotor activity [23]. Animals were treated with vehicle $(10 \mathrm{~mL} / \mathrm{kg}$, i.p.), C. cordiifolius essential oil (100 mg/kg, i.p.), or diazepam $(1 \mathrm{mg} / \mathrm{kg}$, i.p.) $30 \mathrm{~min}$ before the test.

2.14. Statistical Analysis. Data was expressed as mean \pm SEM and analyzed by ANOVA followed by Dunnett's test using GraphPad Prism 5.0 with significance set at $P<0.05$.
TABLE 1: Medicinal uses, number of citations, and use value of Croton cordiifolius Baill. in the central region of state of Pernambuco, Brazil.

\begin{tabular}{lc}
\hline Medicinal uses & Number of citations \\
\hline Inflammation and pain & 39 \\
Wounds & 23 \\
Intestinal disturbances & 19 \\
Liver problems & 7 \\
Itching & 4 \\
Cold & 4 \\
Kidney problems & 4 \\
Fever & 3 \\
Aphrodisiac & 3 \\
Stomach problems & 2 \\
Sinusitis & 1 \\
Bleeding & 1 \\
Diabetes & 1 \\
Total citations & 111 \\
Use value & 1,11 \\
\hline
\end{tabular}

\section{Results and Discussion}

Ethnobotanical data was collected from one hundred people in the cities of Salgueiro, Terra-Nova, Parnamirim, and Serrita between January and March 2011. Most people interviewed were female $(70.5 \%)$, between 40 and 59 years old $(50.5 \%)$, of which $78.8 \%$ knew medicinal plants. The most cited plants were "ameixa" (63.5\%), "aroeira" (61.6\%), and "quebra-faca" (33.0\%). After viewing a specimen of C. cordiifolius, $98 \%$ of the interviewees recognized it as "quebra-faca" citing many medicinal uses for the treatment of inflammation, pain, wounds, and gastrointestinal disturbs. Medicinal uses, number of citations, and use value of $C$. cordiifolius are listed in Table 1.

Fresh leaves of $C$. cordiffolius were extracted in a Clevenger-type apparatus to obtain the essential oil $(0.81 \%)$. Determination of the chemical composition of $C$. cordiifolius essential oil ( $\mathrm{CcEO}$ ) performed by GC/MS and NMR analysis revealed the presence of monoterpenes and sesquiterpenes, including oxygenated compounds, similar to other Croton species [16]. The composition of the oil, including the retention index and the percentage of each constituent, is presented in Table 2 . Analysis by ${ }^{1} \mathrm{H}$ and ${ }^{13} \mathrm{C}$ NMR and comparison with literature data [24] confirmed the presence of 1,8cineole $(25.09 \%)$ and $\alpha$-phellandrene $(15.43 \%)$ as the major components (see Supplementary Data in Supplementary Material available online at http://dx.doi.org/10.1155/2015/ 620865). No scientific report concerning the composition or pharmacological properties of $\mathrm{CcEO}$ could be found in the literature; however the major compounds 1,8-cineole and $\alpha$-phellandrene have been studied. Several pharmacological activities of 1,8-cineole were described, such as antiinflammatory and analgesic, antitussive, antitumoral, gastroprotective, and hepatoprotective activities [25]. The antinociceptive activity of $\alpha$-phellandrene was recently reported in murine models of chemical and mechanical nociception [26]. 
TABLE 2: Chemical composition of the essential oil of Croton cordiifolius Baill. leaves.

\begin{tabular}{|c|c|c|c|c|}
\hline Volatile constituent $^{\mathrm{a}}$ & $\mathrm{RI}^{\mathrm{b}}$ & $\mathrm{RI}^{\mathrm{c}}$ & Retention time (min) & Relative area \% \\
\hline \multicolumn{5}{|l|}{ Monoterpenes } \\
\hline$\alpha$-Pinene & 939 & 937 & 13.88 & 4.96 \\
\hline$\beta$-Phellandrene & 964 & 974 & 16.15 & 4.68 \\
\hline$\alpha$-Phellandrene & 1003 & 1005 & 18.01 & 15.43 \\
\hline$\beta$-Cymene & 1025 & 1024 & 19.21 & 8.02 \\
\hline D-Limonene & 1030 & 1029 & 19.51 & 5.22 \\
\hline \multicolumn{5}{|l|}{ Oxygenated monoterpenes } \\
\hline 1,8-Cineol & 1031 & 1032 & 19.73 & 25.09 \\
\hline$\beta$-Linalool & 1097 & 1097 & 23.67 & 2.34 \\
\hline$\alpha$-Terpineol & 1189 & 1192 & 29.53 & 3.41 \\
\hline \multicolumn{5}{|l|}{ Sesquiterpenes } \\
\hline$\beta$-Caryophyllene & 1419 & 1418 & 43.41 & 6.58 \\
\hline$\gamma$-Elemene & 1430 & 1484 & 47.49 & 7.36 \\
\hline \multicolumn{5}{|l|}{ Oxygenated sesquiterpenes } \\
\hline Spathulenol & 1578 & 1518 & 49.55 & 6.68 \\
\hline$\beta$-Caryophyllene oxide & 1583 & 1520 & 49.69 & 4.72 \\
\hline Cadinol & 1640 & 1534 & 50.59 & 5.51 \\
\hline Total & & & & 100.0 \\
\hline
\end{tabular}

${ }^{\mathrm{a}}$ Constituents listed in order of elution on DB- 5 column.

${ }^{\mathrm{b}} \mathrm{RI}=$ Kovats retention index according to n-alkanes (C8-C26).

${ }^{\mathrm{c}} \mathrm{RI}=$ Kovats retention index simulated by equation $\mathrm{IK}=16.267 \mathrm{RT}+711.48$.

Single dose acute toxicity was assayed through a limit test of $1,000 \mathrm{mg} / \mathrm{kg}$ by intraperitoneal route. Five animals were tested. During the 14-day observation period, one animal died. Gross necropsy showed no macroscopic changes in vital organs. As only one animal died, $\mathrm{LD}_{50}$ value was considered higher than $1,000 \mathrm{mg} / \mathrm{kg}$. Doses of 50 and $100 \mathrm{mg} / \mathrm{kg}$ were chosen for the antinociceptive tests.

In the acetic acid induced writhing, both doses of $\mathrm{CcEO}$ reduced the number of writhing in a dose-dependent manner compared to the control group, as showed in Figure 1. This test is a useful tool to evaluate both central and peripheral analgesic activity of new compounds. Acetic acid induces peritoneal resident cells (macrophages and mast cells) to liberate TNF- $\alpha$ and prostaglandin E2, which produce the noxious stimuli. Anti-inflammatory drugs as indomethacin, a cyclooxygenase inhibitor, are effective in reducing pain [27]. Despite the test being sensitive to weak analgesics, it is also sensitive to other pharmacological agents, such as neuroleptics, anticholinergics, and antihistamines [28]. Both CcEO major compounds 1,8-cineole and $\alpha$-phellandrene, when administrated alone, have been shown to be effective in this animal model $[25,26]$.

The formalin test can be divided into two phases: the neurogenic phase (or first phase) and the inflammatory phase (or second phase). Neurogenic phase initiates at the moment of formalin injection and lasts for 3-5 min. In this phase, pain is mediated by substance $\mathrm{P}$ and bradykinin. The inflammatory phase starts approximately $20 \mathrm{~min}$ after formalin injection and lasts for 5-10 min. In that phase amines (histamine and serotonin), prostaglandins, and bradykinin play the major role. Morphine is an effective inhibitor of both phases whereas nonsteroidal anti-inflammatory drugs and

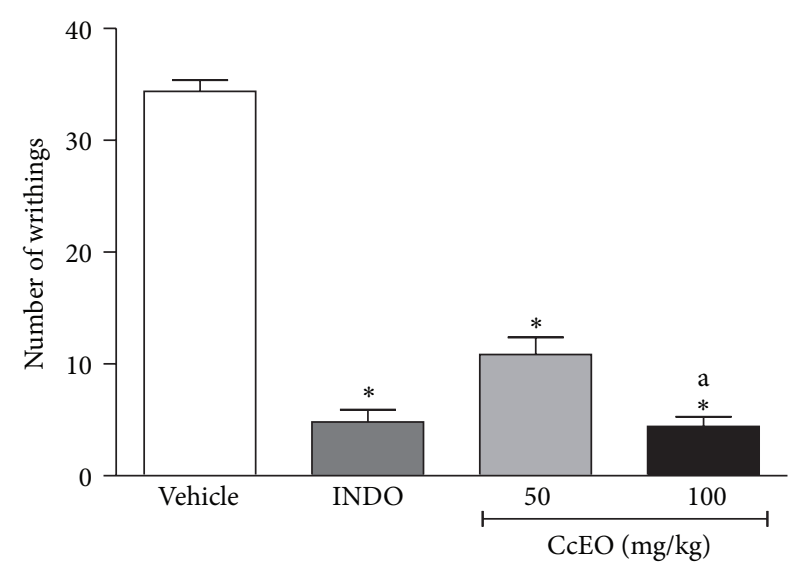

Figure 1: Effect of C. cordiifolius essential oil (CcEO; 50 and $100 \mathrm{mg} / \mathrm{kg}$, i.p.) and indomethacin (INDO; $10 \mathrm{mg} / \mathrm{kg}$, i.p.) in the acetic acid induced writhing test. Results are expressed as mean \pm SEM $(n=8)$ with significance level set at $P<0.05$. ${ }^{*}$ When

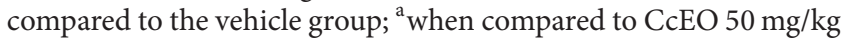
group.

steroids are only effective in the inflammatory phase [20]. Here, in the neurogenic phase both doses (50 and $100 \mathrm{mg} / \mathrm{kg}$ ) of CcEO inhibited the time spent licking the injected paw in a dose-dependent manner. The inhibition in the higher dose was greater than morphine $(7.5 \mathrm{mg} / \mathrm{kg})$. In the inflammatory phase, only the dose of $100 \mathrm{mg} / \mathrm{kg}$ was effective (Figure 2). Santos et al. [25] and Lima et al. [26] described similar results in formalin test for pure 1,8-cineole and $\alpha$-phellandrene, respectively, emphasizing the role of these compounds in the antinociceptive activity of C. cordiifolius essential oil. 


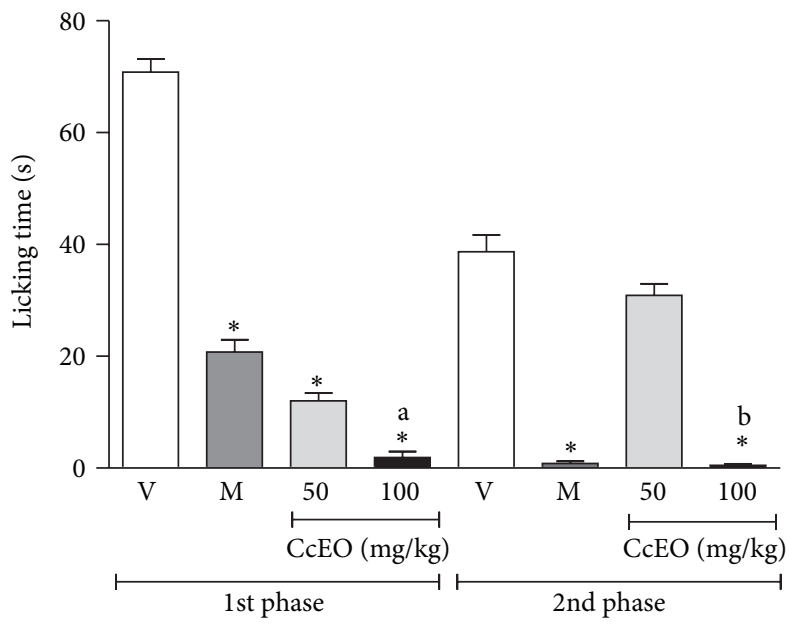

Figure 2: Effect of C. cordiifolius essential oil (CcEO; 50 and $100 \mathrm{mg} / \mathrm{kg}$, i.p.) and morphine (M; $7.5 \mathrm{mg} / \mathrm{kg}$, i.p.) in the nociception induced by intraplantar formalin injection. Results are expressed as mean \pm SEM $(n=8)$ with significance level set at $P<0.05 .{ }^{*}$ When compared to the vehicle (V) group in each phase; ${ }^{a}$ when compared to CcEO $50 \mathrm{mg} / \mathrm{kg}$ group in the first phase; ${ }^{b}$ when compared to CcEO $50 \mathrm{mg} / \mathrm{kg}$ group in the second phase.

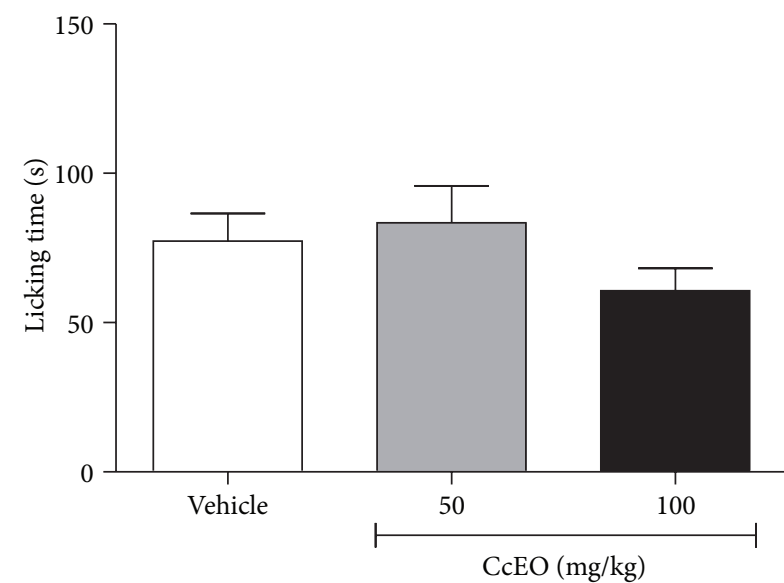

(a)

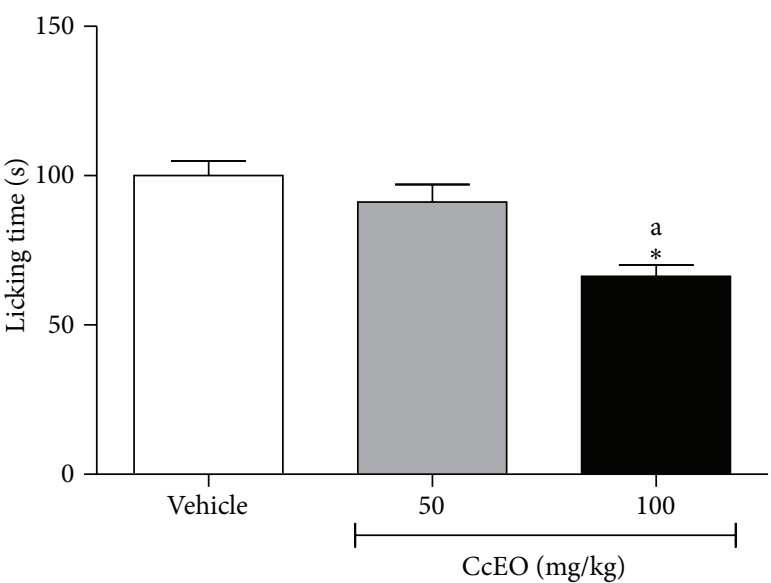

(b)

FIGURE 3: Effect of C. cordiifolius essential oil (CcEO; 50 and $100 \mathrm{mg} / \mathrm{kg}$, i.p.) in the nociception induced by intraplantar capsaicin (a) and glutamate (b) injection. Results are expressed as mean \pm SEM $(n=8)$ with significance level set at $P<0.05$. ${ }^{*}$ When compared to the vehicle group; ${ }^{\mathrm{a}}$ when compared to $\mathrm{CcEO} 50 \mathrm{mg} / \mathrm{kg}$ group.

In order to elucidate the mechanism of action of the CcEO, the nociception induced by intraplantar injection of capsaicin was tested. Capsaicin is a natural product found in chili peppers (Capsicum spp.). Capsaicin is an agonist of TRPV1, an ion channel member of transient receptor potential family, which is enriched in sensory neurons involved in pain perception. TRPV1 can be activated in peripheral neurons by different stimuli, such as heat, acid, vanilloids (e.g., capsaicin and gingerols), and endocannabinoids allowing the transient influx of $\mathrm{Ca}^{2+}[29,30]$. No effect was observed in both doses of CcEO, as showed in Figure 3(a), suggesting that there was no participation of TRPV1 receptors in the antinociceptive effect of $\mathrm{CcEO}$, despite the antinociceptive effect of pure $\alpha$-phellandrene on this animal model [26].
Another test was performed, this time to evaluate the possible role of glutamatergic system in the antinociceptive properties of CcEO, since this is one of the possible mechanisms of action of $\alpha$-phellandrene [26]. Nociceptive response caused by glutamate involves peripheral, spinal, and supraspinal sites and its action is mediated by NMDA and non-NMDA receptors, as well as by nitric oxide (NO) release [22]. NO increases the synthesis/release of inflammatory mediators such as cytokine, reactive oxygen species (ROS), and arachidonic acid derivatives enhancing the inflammatory reaction and the associated pain $[22,26]$. Here, the higher dose of CcEO inhibited the nociception induced by glutamate suggesting the involvement of glutamatergic system in the antinociceptive effect of C. cordiifolius essential oil (Figure 3(b)). 


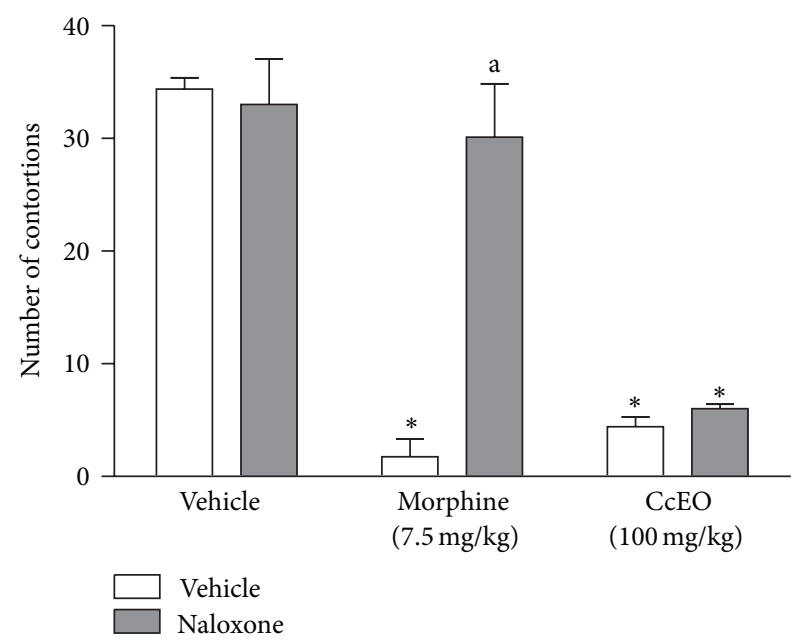

FIGURE 4: Evaluation of the pretreatment with naloxone $(2 \mathrm{mg} / \mathrm{kg}$, i.p.) in the effect of $C$. cordiifolius essential oil (CcEO; 50 and $100 \mathrm{mg} / \mathrm{kg}$, i.p.) and morphine (7.5 mg/kg, i.p.) in the acetic acid induced writhing test. Results are expressed as mean $\pm \operatorname{SEM}(n=8)$ with significance level set at $P<0.05$. ${ }^{*}$ When compared to the vehicle group; ${ }^{a}$ when compared to morphine group.

To evaluate the role of endogenous opioids on the antinociceptive effect of $\mathrm{CcEO}$, naloxone, an opioid antagonist was evaluated in another writhing test [22]. The results presented in Figure 4 show that when naloxone $(1 \mathrm{mg} / \mathrm{kg}$, i.p.) was given to mice $15 \mathrm{~min}$ before CcEO (50 and $100 \mathrm{mg} / \mathrm{kg}$, i.p.) or morphine (7.5 mg/kg, i.p.), the antinociceptive effect of morphine was completely reversed. However, naloxone was not able to modify the antinociceptive effect caused by the $\mathrm{CcEO}$ in the writhing test, indicating that the endogenous opioid system is not involved in the antinociceptive activity of CcEO.

The antinociceptive effect of plant extracts and isolated compounds are usually evaluated by behavioral tests. Several drugs as muscle relaxants and sedatives can mask those tests with false positive results [31]. To eliminate this possibility, the open field method was performed. CcEO $(100 \mathrm{mg} / \mathrm{kg})$ did not alter the number of squares crossed, rearing and grooming when compared with vehicle. On the other hand, animals treated with diazepam $(1 \mathrm{mg} / \mathrm{kg}$, i.p.) reduced all evaluated parameters. These results suggest that $\mathrm{CcEO}$ did not have sedative or stimulant effects on central nervous system (CNS) [31].

\section{Conclusions}

In the present work, it was verified that $C$. cordiifolius is well known and used as medicinal plant in the semiarid region of the northeast of Brazil. The main constituents of its essential oil obtained by hydrodistillation were 1,8 -cineole and $\alpha$ phellandrene. $\mathrm{CcEO}$ showed antinociceptive effect in murine models of chemical induced pain without the participation of endogenous opioid system and TRPV1 channels. No sedative or stimulant effect on CNS was observed in open field test. The effect of $C$. cordiifolius essential oil could be explained, at least in part, by the inhibition of glutamatergic system.

\section{Conflict of Interests}

The authors have declared that there is no conflict of interests.

\section{Acknowledgments}

The authors are grateful to CNPq, CAPES, and FACEPE for the financial support. The authors also wish to thank the botanist Maria Olívia de Oliveira Cano for botanical authentication. Language revision of this paper was made by Editage.

\section{References}

[1] P. E. Berry, A. L. Hipp, K. J. Wurdack, B. Van Ee, and R. Riina, "Molecular phylogenetics of the giant genus Croton and tribe Crotoneae (Euphorbiaceae sensu stricto) using ITS and trnLtrnF DNA sequence data," The American Journal of Botany, vol. 92, no. 9, pp. 1520-1534, 2005.

[2] A.-F. M. Rizsk, "The chemical constituents and economic plants of the Euphorbiaceae," Botanical Journal of the Linnean Society, vol. 94, no. 1-2, pp. 293-326, 1987.

[3] E. J. B. Bighetti, C. A. Hiruma-Lima, J. S. Gracioso, and A. R. M. S. Brito, "Anti-inflammatory and antinociceptive effects in rodents of the essential oil of Croton cajucara benth," Journal of Pharmacy and Pharmacology, vol. 51, no. 12, pp. 1447-1453, 1999.

[4] A. C. Oliveira, J. H. Leal-Cardoso, C. F. Santos, S. M. Morais, and A. N. Coelho-de-Souza, "Antinociceptive effects of the essential oil of Croton zehntneri in mice," Brazilian Journal of Medical and Biological Research, vol. 34, no. 11, pp. 1471-1474, 2001.

[5] L. Pieters, T. de Bruyne, B. van Poel et al., "In vivo wound healing activity of Dragon's blood (Croton spp.): a traditional South American drug, and its constituents," Phytomedicine, vol. 2, no. 1, pp. 17-22, 1995.

[6] A. Salantino, M. L. F. Salantino, and G. Negri, "Traditional uses, chemistry and pharmacology of Croton species (Euphorbiaceae)," Journal of the Brazilian Chemical Society, vol. 18, pp. 11-33, 2007.

[7] F. A. Santos, F. A. Jeferson, C. C. Santos, E. R. Silveira, and V. S. N. Rao, "Antinociceptive effect of leaf essential oil from Croton sonderianus in mice," Life Sciences, vol. 77, no. 23, pp. 2953-2963, 2005.

[8] R. M. Ximenes, L. D. M. Nogueira, N. M. R. Cassundé et al., "Antinociceptive and wound healing activities of Croton adamantinus Müll. Arg. essential oil," Journal of Natural Medicines, vol. 67, no. 4, pp. 758-764, 2013.

[9] D. R. Cavalcanti and U. P. Albuquerque, "The 'hidden diversity' of medicinal plants in northeastern Brazil: diagnosis and prospects for conservation and biological prospecting," Evidence-Based Complementary and Alternative Medicine, vol. 2013, Article ID 102714, 29 pages, 2013.

[10] J. M. Monteiro, M. A. Ramos, E. D. L. Araújo, E. L. C. Amorim, and U. P. Albuquerque, "Dynamics of medicinal plants knowledge and commerce in an urban ecosystem (Pernambuco, Northeast Brazil)," Environmental Monitoring and Assessment, vol. 178, no. 1-4, pp. 179-202, 2011.

[11] S. L. Cartaxo, M. M. de Almeida Souza, and U. P. de Albuquerque, "Medicinal plants with bioprospecting potential used in semi-arid northeastern Brazil," Journal of Ethnopharmacology, vol. 131, no. 2, pp. 326-342, 2010. 
[12] C. D. F. C. B. R. de Almeida, M. A. Ramos, E. L. C. de Amorim, and U. P. de Albuquerque, "A comparison of knowledge about medicinal plants for three rural communities in the semi-arid region of northeast of Brazil," Journal of Ethnopharmacology, vol. 127, no. 3, pp. 674-684, 2010.

[13] S. C. Rossato, H. D. F. Leitão-Filho, and A. Begossi, "Ethnobotany of Caiçaras of the Atlantic Forest coast (Brazil)," Economic Botany, vol. 53, no. 4, pp. 387-395, 1999.

[14] S. Stein, G. Mallard, A. Levitsky, and O. Fatecy, NIST MS Library Database, National Institute of Standards and Technology, 1997.

[15] R. P. I. Adams, Identification of Essential Oil Components by Gas Chromatography/Quadrupole Mass Spectroscopy, Allured, Carol Stream, Ill, USA, 3rd edition, 2001.

[16] A. A. Craveiro, A. S. Rodrigues, C. H. S. Andrade, F. J. A. Matos, J. W. Alencar, and M. I. L. Machado, "Volatile constituents of Brazilian Euphorbiaceae genus Croton," Journal of Natural Products, vol. 44, no. 5, pp. 602-608, 1981.

[17] J. W. Alencar, A. A. Craveiro, F. J. A. Matos, and M. L. I. Machado, "Kovats indices simulation in essential oil analysis," Química Nova, vol. 13, pp. 282-284, 1990.

[18] OECD (Organisation for Economic Co-Operation and Development), "Test no. 425: acute oral toxicity: up-and-down procedure," in OECD Guidelines for the Testing of Chemicals, Section 4: Health Effects, 2008.

[19] R. Koster, M. Anderson, and J. De Beer, "Acetic acid for analgesic screening," Federation Proceedings, vol. 18, pp. 412-417, 1959.

[20] S. Hunskaar and K. Hole, "The formalin test in mice: dissociation between inflammatory and non-inflammatory pain," Pain, vol. 30, no. 1, pp. 103-114, 1987.

[21] A. R. S. Santos, A. P. Trentin, J. Ferreira, R. A. Yunes, and J. B. Calixto, "Mechanisms involved in the antinociception caused by compound MV8612 isolated from Mandevilla velutina in mice," Brain Research, vol. 961, no. 2, pp. 269-276, 2003.

[22] G. Guginski, A. P. Luiz, M. D. Silva et al., "Mechanisms involved in the antinociception caused by ethanolic extract obtained from the leaves of Melissa officinalis (lemon balm) in mice," Pharmacology Biochemistry and Behavior, vol. 93, no. 1, pp. 1016, 2009.

[23] S. C. Lopes, A. V. L. Da Silva, B. R. Arruda et al., "Peripheral antinociceptive action of mangiferin in mouse models of experimental pain: role of endogenous opioids, KATP-channels and adenosine," Pharmacology Biochemistry and Behavior, vol. 110, pp. 19-26, 2013.

[24] E. R. Silveira, G. T. Malcher, C. C. Santos, and M. A. S. Lima, "Unidimensional NMR, very simple but important tool for plant populational studies: Croton sonderianus Muell Arg," Annals of Magnetic Resonance, vol. 3, no. 3, pp. 99-101, 2004.

[25] F. A. Santos, R. M. Silva, A. R. Campos, R. P. de Araújo, R. C. P. Lima Júnior, and V. S. N. Rao, "1,8-Cineole (eucalyptol), a monoterpene oxide attenuates the colonic damage in rats on acute TNBS-colitis," Food and Chemical Toxicology, vol. 42, no. 4, pp. 579-584, 2004.

[26] D. F. Lima, M. S. Brandã, J. B. Moura et al., "Antinociceptive activity of the monoterpene $\alpha$-phellandrene in rodents: possible mechanisms of action," Journal of Pharmacy and Pharmacology, vol. 64, no. 2, pp. 283-292, 2012.

[27] R. A. Ribeiro, M. L. Vale, S. M. Thomazzi et al., "Involvement of resident macrophages and mast cells in the writhing nociceptive response induced by zymosan and acetic acid in mice," European Journal of Pharmacology, vol. 387, no. 1, pp. 111-118, 2000.
[28] J. S. Mogil, S. G. Wilson, and Y. Wan, "Assessing nociception in murine subjects," in Methods in Pain Research, L. Kruger, Ed., pp. 26-27, CRC Press, 2001.

[29] M.-K. Chung, A. D. Güler, and M. J. Caterina, "TRPV1 shows dynamic ionic selectivity during agonist stimulation," Nature Neuroscience, vol. 11, no. 5, pp. 555-564, 2008.

[30] T. B. Nguelefack, R. C. Dutra, A. F. Paszcuk, E. L. Andrade, L. A. Tapondjou, and J. B. Calixto, "Antinociceptive activities of the methanol extract of the bulbs of Dioscorea bulbifera $\mathrm{L}$. var sativa in mice is dependent of NO-cGMP-ATP-sensitive- $\mathrm{K}^{+}$channel activation," Journal of Ethnopharmacology, vol. 128, no. 3, pp. 567-574, 2010.

[31] F. H. C. Melo, E. R. V. Rios, N. F. M. Rocha et al., "Antinociceptive activity of carvacrol (5-isopropyl-2-methylphenol) in mice," Journal of Pharmacy and Pharmacology, vol. 64, no. 12, pp. 1722$1729,2012$. 


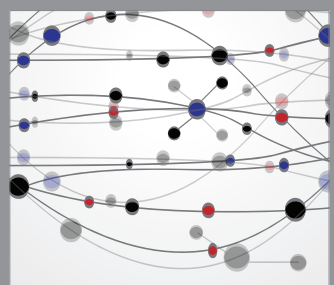

The Scientific World Journal
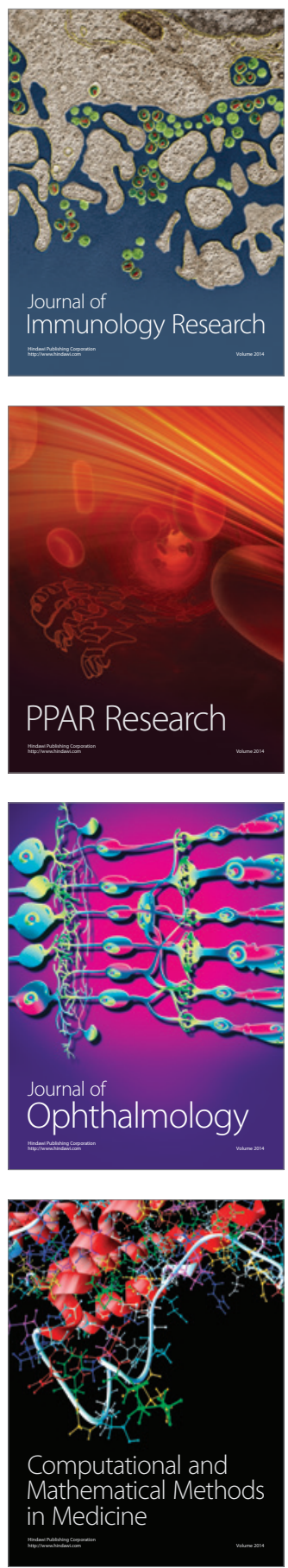

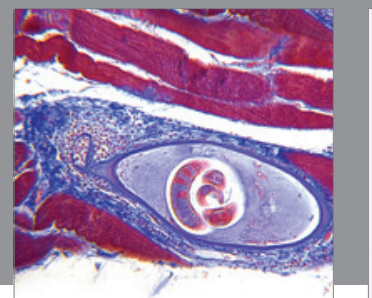

Gastroenterology

Research and Practice
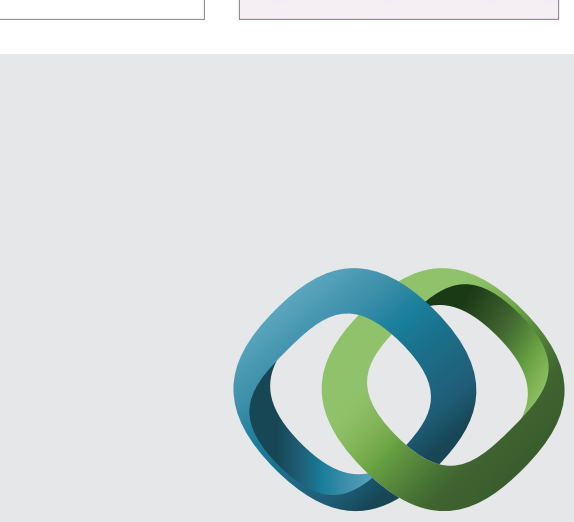

\section{Hindawi}

Submit your manuscripts at

http://www.hindawi.com
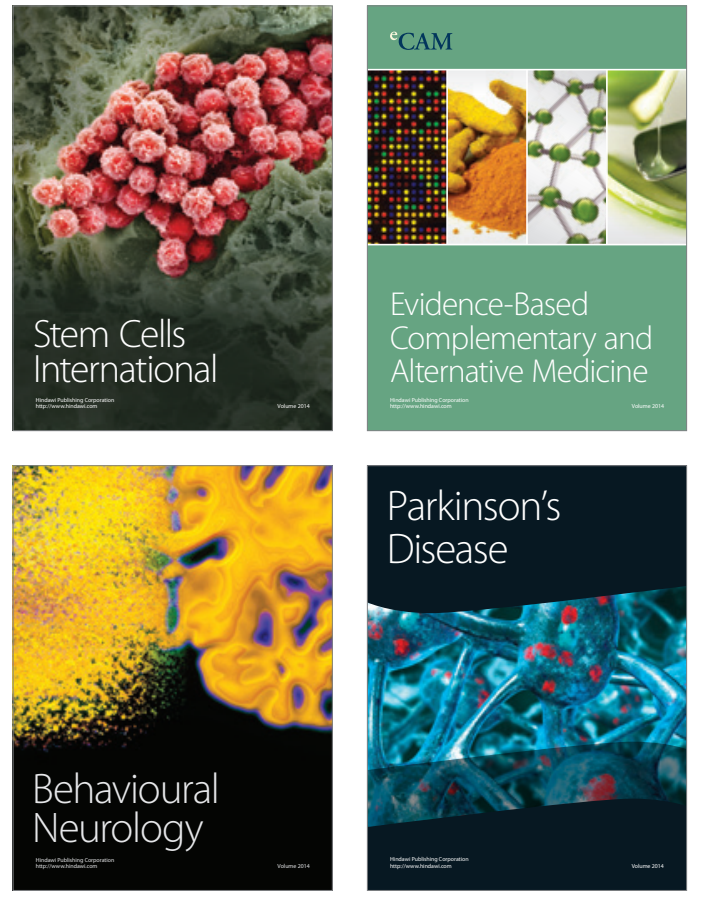
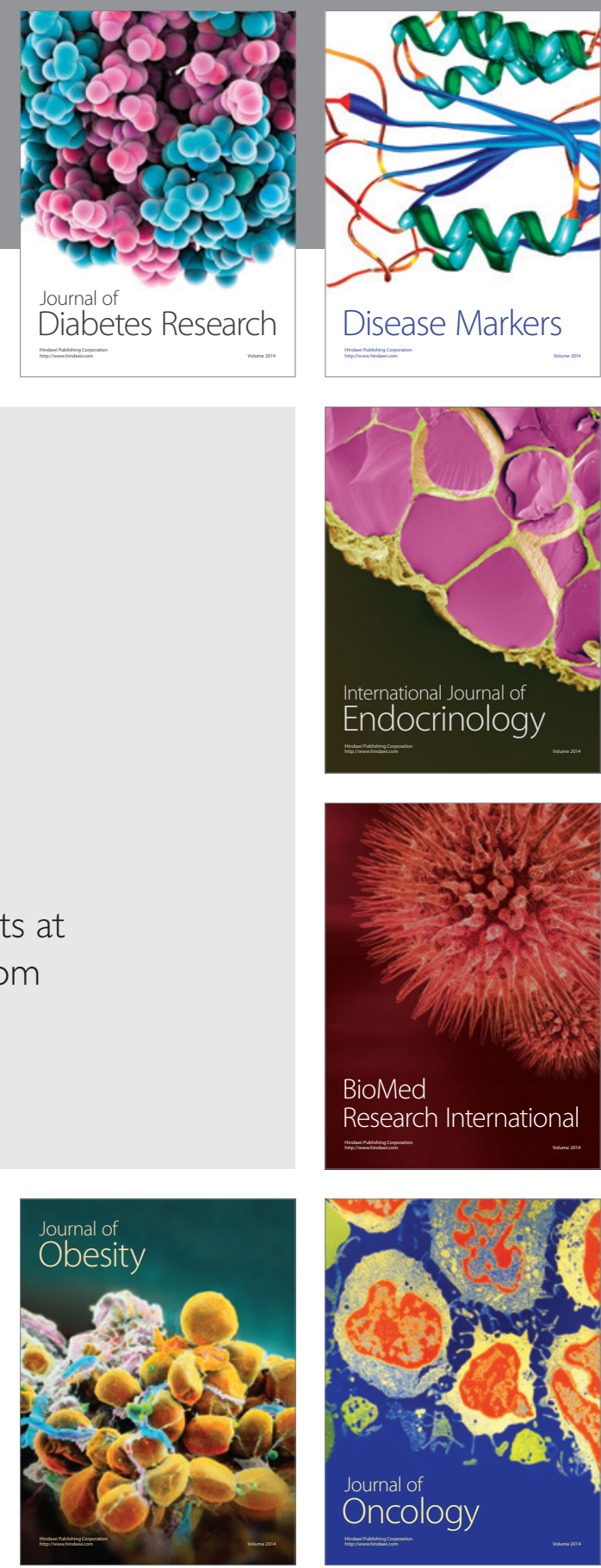

Disease Markers
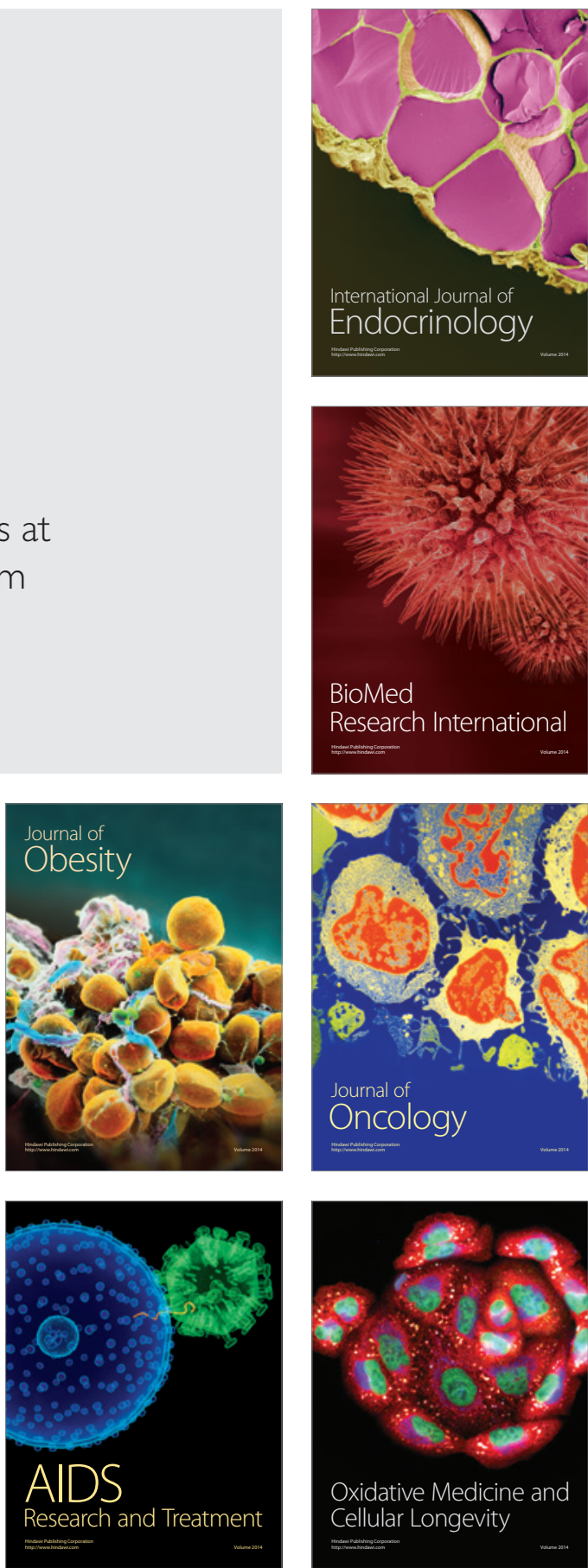